\title{
Holocene changes in trophic states of shallow lakes from the Pampa plain of Argentina
}

\author{
Silvina Stutz,' C Marcela Borel, ${ }^{2}$ Sonia L Fontana ${ }^{3,4}$ and \\ Marcela S Tonello'
}

\begin{abstract}
Changes in trophic status of shallow lakes from the southeastern Pampa plain of Argentina are evaluated based on the relative presence of submerged macrophytes and phytoplankton. The evolution of lake Lonkoy is reconstructed for the last 5000 years, using pollen, non-pollen palynomorphs (NPPs) and macrofossil remain analyses, revealing three main lake stages. A macrophyte-dominated clear lake prevailed until 670 cal yr BP. Afterwards, the lake changed to a turbid phytoplankton-dominated state. Recently, the lake has turned to a turbid phase, caused by resuspended sediment. These results are compared with two other paleolimnological records from the region, lakes Hinojales and Nahuel Rucá, revealing a similar late-Holocene evolution, with a shift from a macrophyte- to phytoplankton-dominated lake, occurring at broadly the same time. The shift of states may be attributed to a shift in climate after $1000 \mathrm{cal}$. yr BP towards wetter conditions during the Medieval Climate Anomaly.
\end{abstract}

\author{
Keywords \\ alternative stable states, late Holocene, palaeolimnology, Pampa plain, shallow lakes, Southern South America
}

Received I5 September 20II; revised manuscript accepted 23 March 2012

\section{Introduction}

Some ecosystems such as lakes, woodlands and deserts can be found in one of several possible alternative stable states. This idea considers that the fluctuations around trends in ecosystems are interrupted by sudden shifts leading to a different persistent dynamics regime (Beisner et al., 2003). Ecological regime shifts, a term which is increasingly used, are sudden changes in ecosystems that last for substantial periods in time. These changes, that drastically make the transition from one persistent dynamic regime to another, may be due to different mechanisms, such a drastic impact on a system, or a stepwise change in some important external condition (Scheffer and Carpenter, 2003; Scheffer and Jeppesen, 2007; Scheffer et al., 2001). The obvious intuitive explanation for a sudden dramatic change in nature is the occurrence of a sudden external impact.

The dynamics of shallow lakes provide the best limnological example of alternative stable states (Scheffer et al., 1993, 2001). Shallow eutrophic lakes exist in two states: in a clear state, dominated by macrophytes (usually rooted aquatic plants, but sometimes attached macroalgae) or in a turbid state, dominated by phytoplankton. The pristine state of a shallow lake is characterized by clear water, submerged vegetation and strong communities of fish and invertebrates. The turbid state, equally stable, is less species-rich and less diverse, with absence of submerged vegetation, fish communities and invertebrates.

Many ecological mechanisms are probably involved in the feedback of the two alternative equilibrium systems. The switch to the clear state can, for example, be triggered by a trophic cascade: piscivore stocking and/or planktivore removal to increase grazing and reduce phytoplankton (Jeppesen et al., 1990; Moss et al., 1996; van Donk and Gulatti, 1995); while the switch to the turbid state can be triggered by water-level fluctuations (Blindow et al., 1993) and/or grazing of macrophytes by fish or birds (van Donk and Gulatti, 1995). According to Scheffer et al. (1993) the whole feedback system is thought to center around the interaction between submerged vegetation and turbidity. Submerged vegetation plays an important role in forming a clear macrophyte-dominated state in shallow lakes. It enhances water clarity by reducing resuspension and provides refuge to zooplankton from grazing by planktivorous fish. Submerged plants also suppress algal growth by competition for nutrients, and by releasing allelophatic substances. Vegetation can stabilize a clear-water state in shallow lakes up to relatively high nutrient loadings, but once the system has switched to a turbid state, it takes a strong nutrient reduction to enable recolonization by plants. In contrast, high turbidity in lake water lowers light availability to submerged plants and reduces their growth. Therefore, extreme perturbation is needed to shift a lake between a clear macrophyte-dominated state and a turbid phytoplankton-dominated state.

Knowledge of past trophic state changes in shallow lakes may provide additional evidence for the alternative equilibrium

\footnotetext{
'Universidad Nacional de Mar del Plata,Argentina

2Universidad Nacional del Sur, Argentina

${ }^{3}$ University of Göttingen, Germany

${ }^{4}$ Queen's University Belfast, UK

Corresponding author:

Silvina Stutz, Laboratorio de Paleoecología y Palinología, Instituto de Investigaciones Marinas y Costeras (IIMyC), FCEyN, Universidad Nacional de Mar del Plata-CONICET, Funes 3250, (7600) Mar del Plata, Argentina.

Email: smstutz@mdp.edu.ar
} 
hypothesis (Scheffer et al., 1993), as well as information regarding natural variability and critical nutrient concentrations. Longterm studies on lake trophic changes are few: e.g. Blindow et al. (1993), Hargeby et al. (2004, 2007), Sayer et al. (2010) at centennial scale; Karst and Smol (2000), Herzschuh et al. (2005), García-Rodriguez et al. (2010), Stutz et al. (2010) at millennial scale.

In the Pampa plain of Argentina, there are a great number of shallow lakes. Most of them are turbid lakes due to the high amount of algae, while few are clear macrophyte-dominated lakes. A third type of lake that can be recognized within the region is inorganic-turbid lakes, in which turbidity is caused by high amount of suspended inorganic material (Allende et al., 2009; Quirós et al., 2002). These lakes are characterized by low productivity, with scarce phytoplankton and macrophytes.

Few studies have inferred the evolutionary history of shallow lakes in the south and southeastern Pampa plain during the Holocene (Borel et al., 2003; Fontana, 2005; Stutz et al., 2002, 2006). Particularly, a multiproxy study at lake Nahuel Rucá demonstrated clear to turbid state shifts during the late Holocene (Stutz et al., 2010).

In this paper, we present the late-Holocene evolution of lake Lonkoy, based on pollen, non-pollen palynomorphs (NPPs) and plant macrofossil analyses. We integrate and compare these results with two other paleolimnological records from the region: lakes Hinojales (Borel et al., 2003; Stutz et al., 2002, 2006) and Nahuel Rucá (Stutz et al., 2010). In this respect, we focused on the relative presence of submerged macrophytes and planktonic algae to explore alternative stable states in these aquatic systems in order to provide evidence of the alternative stable states theory at millennial scale. Within the framework of this theory we aim at providing a likely scenario explaining these shifts.

\section{Study area}

Lonkoy $\left(37^{\circ} 12^{\prime} \mathrm{S} ; 57^{\circ} 25^{\prime} \mathrm{W}\right)$, Nahuel Rucá $\left(37^{\circ} 37^{\prime} \mathrm{S} ; 57^{\circ} 26^{\prime} \mathrm{W}\right)$ and Hinojales $\left(37^{\circ} 34^{\prime} \mathrm{S} ; 57^{\circ} 27^{\prime} \mathrm{W}\right)$ are small, freshwater shallow lakes (200-300 ha; less than $1.5 \mathrm{~m}$ deep), situated in the southeastern Pampa plain (Buenos Aires province, Argentina) (Figure 1).
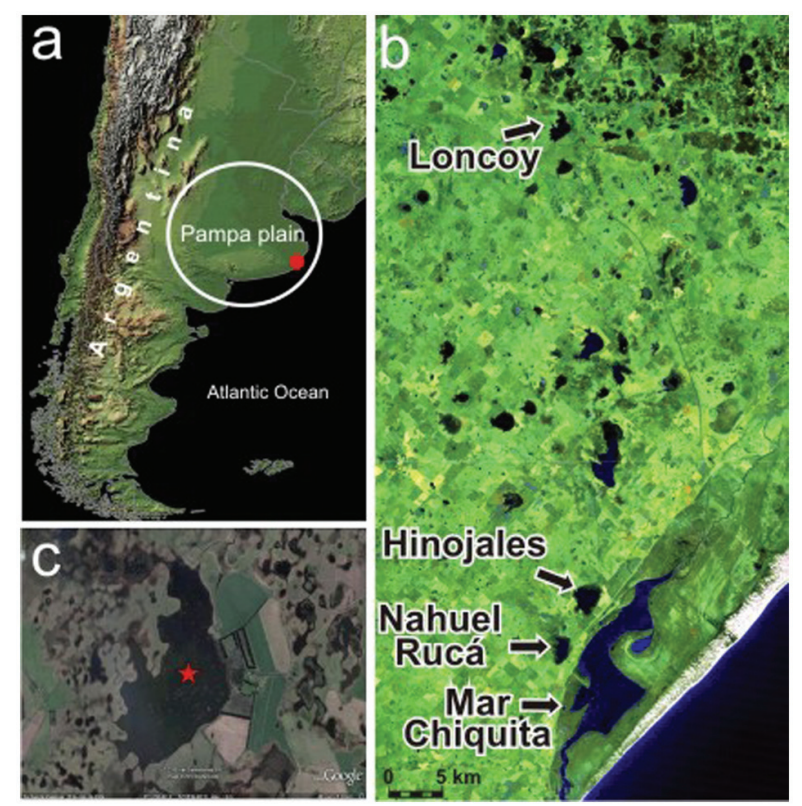

Figure I. (a) Location of study area. (b) General overview of lakes Lonkoy, Nahuel Rucá and Hinojales. (c) Study site, lake Lonkoy. Asterisk: sampling point. LNT LandSat7 (False color). Source:World Wind I.4 http//:worldwind.arc.nasa.gov/.
These lakes, like most lakes in the region, are deflation basins situated on the windward side of paleodunes. These basins and associated paleodunes were probably formed by prevailing westerly winds during the Late Pleistocene (Tricart, 1973) and became areas of groundwater discharge and surface water accumulation gradually filling with sediments, during the Holocene. Although the three lakes are permanent and shallow systems, during summer and/or during episodic droughts they suffer significant reduction in water volume, and thus strong fluctuations in their water levels.

The eastern part of Buenos Aires province was affected by sea-level fluctuations during the Holocene. In the study area sea level reached a maximum height of 2.0-2.5 m a.s.l. between $c$. 6000 and $5500 \mathrm{yr}$ BP (Violante et al., 2001), transgressing the area about $10 \mathrm{~km}$ from the present seashore (Figure 1; Stutz et al., 2006, 2010; Violante, 1992). During the regressive phase, the coastal areas adjacent to the seashore evolved, resulting in the formation of large coastal plains, barriers and lagoons.

The modern regional vegetation of the study area is characterized by several genera of grasses. It lacks native trees and the landscape is strongly anthropogenically influenced and intensively used for agriculture and grazing. The local vegetation is characterized by sedges (Cyperus, Carex, Schoenoplectus and Eleocharis), grasses (Paspalum, Stipa, Panicum, Polypogon, Glyceria, Paspalidium), several species of Juncus and herbaceous dicots (Eryngium, Aster, Daucus, Phyla) (Vervoorst, 1967). In particular, the lake plant communities are characterized by several species of emergent, free-floating leaved and submerged macrophytes. The dominant species is Schoenoplectus californicus, which forms a complete ring around the lakes. Other emergent macrophytes grow into the ring of Schoenoplectus in the shallowest zones: Zizaniopsis bonariensis, Hydrocotyle bonariensis, H. ranunculoides, Alternanthera philloxeroides, Solanum glaucophyllum, Bacopa monnieri, Polygonum punctatum, Ranunculus apiifolius, Triglochin striata and Phyla canescens. Near the shore, Ricciocarpus natans (a liverworth), Azolla filiculoides (a fern), Lemna valdiviana and Wolffiella lingulata form a dense carpet. Myriophyllum elatinoides and Ceratophyllum demersum develop in deepest parts but also at the shore when there is no other vegetation.

The climate is temperate with annual mean temperature and precipitation of $13.8^{\circ} \mathrm{C}$ and $941 \mathrm{~mm}$, respectively (Mar del Plata Aero meteorological station, $37^{\circ} 33.6^{\prime} \mathrm{S}, 57^{\circ} 21^{\prime} \mathrm{W}$, Servicio Meteorológico Nacional). Mean temperature varies from $20^{\circ} \mathrm{C}$ in January to $7.3^{\circ} \mathrm{C}$ in July. Rainfall occurs mainly from spring (September) to autumn (March), with a maximum of $112.3 \mathrm{~mm}$ in February and a minimum of $45.3 \mathrm{~mm}$ in August. During summer, most frequent winds are from the N, NE and E directions turning NW to SW in winter.

\section{Methodology}

\section{Fieldwork and sampling}

A $142 \mathrm{~cm}$ long core was recovered from the deepest part of lake Lonkoy with a modified Livingston corer, in April 2009. In the laboratory, the core was described and sectioned at contiguous 1 $\mathrm{cm}$ intervals. Samples of $1-5 \mathrm{~g}$ were analyzed contiguously for determination of organic matter content. Samples of $2-6 \mathrm{~cm}^{3}$ were taken at $2-4 \mathrm{~cm}$ intervals for analysis of macro remains. Pollen and NPPs were analyzed at 1-2 cm intervals. Lithologic description was based on visual inspection.

\section{Laboratory methods}

Organic matter content was estimated by weight loss-on-ignition (LOI). Samples were oven-dried at $105^{\circ} \mathrm{C}$ for $24 \mathrm{~h}$, and then 
heated in a muffle furnace at $550^{\circ} \mathrm{C}$ for $4 \mathrm{~h}$. Results are expressed as a percentage of weight loss of the sediment related to the dry weight of the samples before combustion (Heiri et al., 2001).

Samples for pollen and non-pollen palynomorph analysis were prepared following standard techniques, using warm $\mathrm{KOH}, \mathrm{HCl}$, heavy-liquid separation with $\mathrm{ZnCl} 2$, $\mathrm{HF}$ and acetolysis (Faegri and Iversen, 1992). Two Lycopodium clavatum tablets were added before treatment. At least 300 pollen grains, including terrestrial and aquatic vascular taxa, were counted for most samples. Each pollen type was calculated as a percentage of the total pollen sum (terrestrial and aquatics). NPPs were calculated as a percentage of the pollen sum plus NPPs sum. Percentage of Azolla filiculoides, Ricciocarpus natans and Bryophyta spores were calculated as percentage of the pollen sum plus spores sum. Identifications of pollen grains, spores and NPPs were carried out using atlases and published keys (Borel, 2007; Borel et al., 2003; Markgraf and D'Antoni, 1983) and the reference collection of the laboratory of Paleoecology and Palynology, Universidad Nacional de Mar del Plata and Laboratory of Palynology, Universidad Nacional del Sur.

Samples for plant macrofossils remains and accompanying biota were treated with $\mathrm{KOH} 10 \%$ for $12 \mathrm{~h}$ and sieved through 200 and $100 \mu \mathrm{m}$ mesh. Chara gyrogonites and oospores were preliminary classified according to length, color of the oospore and number of ridges into three groups: Chara sp. A, B and C. Zones were defined using CONNISS (Grimm, 1987). Taxa exceeding $2 \%$ of the total pollen sum in at least one sample were considered for the zonation of the pollen diagram. For the zonation of macrofossils only Charophyte and plant remains were considered.

Proxy analysis of lakes Hinojales and Nahuel Rucá followed the same methods. For more details, see Stutz et al. (2002, 2006, 2010).

In order to compare the three lakes, submerged macrophytes Myriophyllum, Potamogeton, Ruppia and Ceratophyllum were plotted against planktonic algae Pediastrum, Scenedesmus, Botryococcus and Tetraedron.

\section{Chronology}

Where possible, terrestrial plant remains were selected for age determination; however, their occurrence in pampean lakes is often scarce. Among the material available for dating, gastropod shells of Heleobia parchappii are usually abundant in sequences recovered from those lakes, and they have shown to be reliable material for dating, despite their potential hard-water-lake effect that could cause radiocarbon dates on shells to be too old. A study in a similar ecosystem of the southwestern Pampa plain, however, demonstrated there was no effect on dated Heleobia parchappii shells (Fontana, 2007). Even though such an evaluation should be done on each system studied, the co-ocurrence of the same pattern in the three lakes considered in this study, allowed us to consider dates on shells reliable for this study. The chronology of the studied cores was determined using AMS radiocarbon dating. Eight dates were obtained on Heleobia parchappii shells and three dates on Schoenoplectus californicus achenes (Table 1). Radiocarbon ages were calibrated against the Southern Hemisphere curve (SHCal04) (McCormac et al., 2004) using the program CALIB 5.0.1 (Stuiver et al., 2005). In view of the dynamic sediment deposition, evident in the lithological changes of the sediment records, core stratigraphy and biological proxy diagrams are plotted against depth. Calibrated ages are indicated to the left of each diagram.

\section{Results}

\section{Lake Lonkoy}

The sediment core was divided into three lithological units (Figure 2). The lowermost sediments $(142-75 \mathrm{~cm})$ consist of clayey silt with abundant Heleobia parchappii shells. LOI values were low $(<10 \%)$, increasing slightly towards the top of the unit. From 75 to $15 \mathrm{~cm}$ depth the core consists of sandy silt sediments. In this unit, LOI values increase gradually up to $40 \%$ at $30 \mathrm{~cm}$ depth; then values fluctuate between $40 \%$ and $75 \%$. The topmost $15 \mathrm{~cm}$ are characterized by black silt sediments and by the highest percentage values of organic matter, $80 \%$.

Three Pollen Assemblage Zones (PAZ) were identified (Figure 2).

PAZ I $(142-75 \mathrm{~cm})$ is characterized by maximum values of Chenopodiaceae, accompanied by Cyperaceae and Myriophyllum, with increasing values towards the top of the zone; Poaceae and Asteroideae are present with low and relatively stable values $(\leq 10 \%)$. This zone presents the maximum values of Ruppia and Potamogeton of the whole sequence. Among the NPPs, maximum values of the dinoflagellate Peridinium and eggs of crustacean Cobricosphaeridium are present. At the top of the zone, Peridinium decreases abruptly, meanwhile chlorococcales (Pediastrum, Scenedesmus, Botryococcus, Tetraedron) and cyanobacterias

Table I. AMS radiocarbon dates from lakes Hinojales, Nahuel Rucá and Lonkoy.

\begin{tabular}{|c|c|c|c|c|}
\hline Sample depth (cm) & Dated material & ${ }^{14} \mathrm{C}$ age $\mathrm{BP}$ & Cal. yr BP median probability ( $2 \sigma$ range) & Laboratory no. \\
\hline \multicolumn{5}{|l|}{ Lake Hinojales $^{\mathrm{a}}$} \\
\hline $58-62$ & S. californicus achenes & $440 \pm 50$ & $460(320-520)$ & Beta-I I 4747 \\
\hline $102-107$ & H. parchappii shells & $4240 \pm 60$ & $4710(4530-4850)$ & Beta- 118012 \\
\hline \multicolumn{5}{|l|}{ Lake Nahuel Rucáb } \\
\hline $51-53$ & S. californicus achenes & $330 \pm 35$ & $390(300-460)$ & AA66206 \\
\hline $71-72$ & S. californicus achenes & $870 \pm 35$ & $740(680-790)$ & AA66205 \\
\hline $83-84$ & H. parchappii shells & $3480 \pm 40$ & $3680(3570-3830)$ & Beta-193897 \\
\hline \multicolumn{5}{|l|}{ Lake Lonkoyc } \\
\hline 79-80 & H. parchappii shells & $770 \pm 35$ & $670(570-730)$ & AA8709I \\
\hline 89-90 & H. parchappii shells & $1310 \pm 35$ & $1200(1080-1280)$ & AA89347 \\
\hline$|00-10|$ & H. parchappii shells & $1830 \pm 35$ & $1700(1600-1820)$ & AA92536 \\
\hline $110-111$ & H. parchappii shells & $2300 \pm 35$ & $2240(2150-2280)$ & AA92537 \\
\hline$|20-| 2 \mid$ & H. parchappii shells & $3540 \pm 40$ & $3760(3640-3870)$ & AA89348 \\
\hline $142-143$ & H. parchappii shells & $4325 \pm 40$ & $4840(4650-4970)$ & AA87092 \\
\hline
\end{tabular}

${ }^{a}$ Stutz et al. (2002).

bStutz et al. (2010).

'This study. 


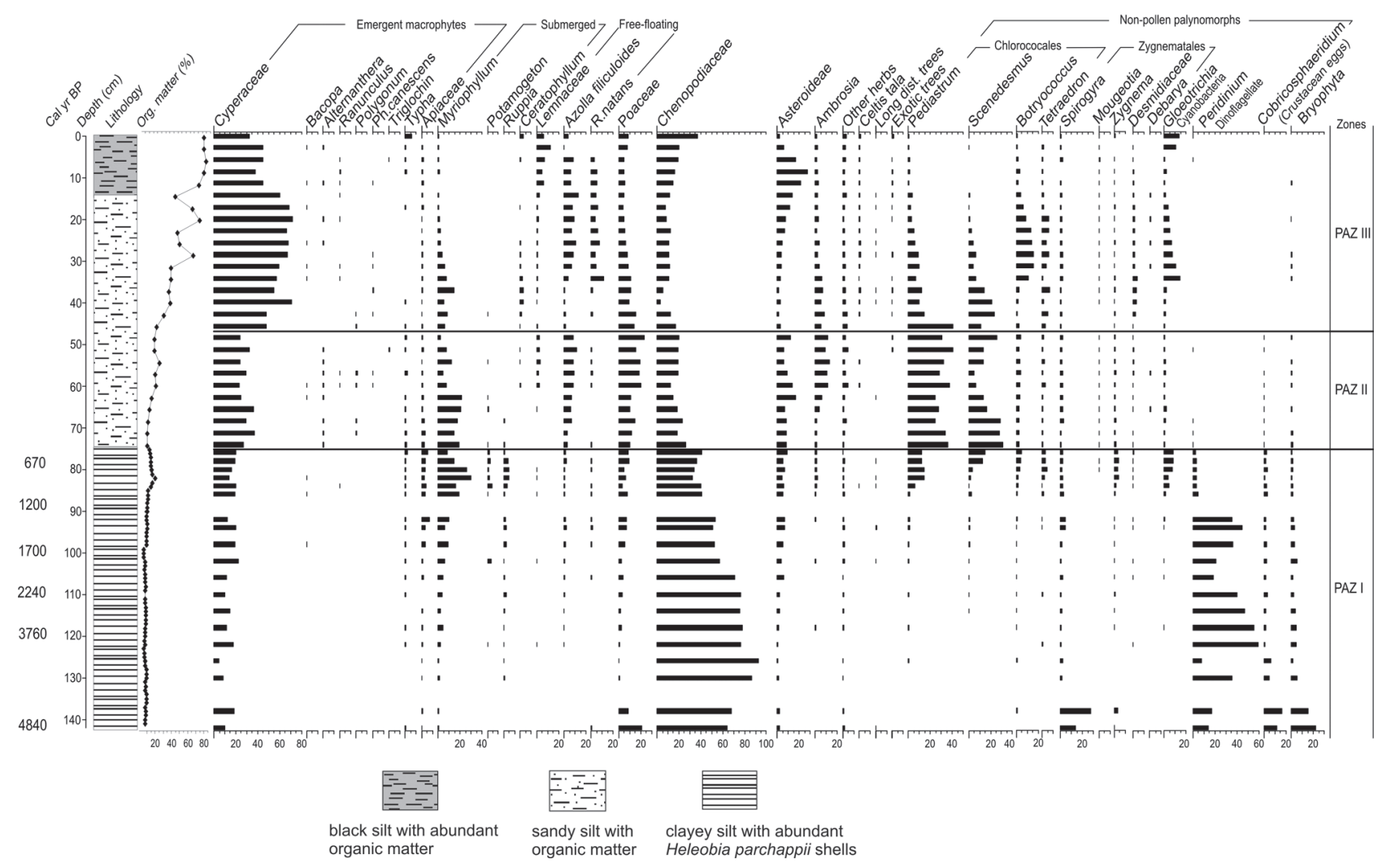

Figure 2. Pollen and non-pollen palynomorph percentages and organic matter content (\%) from lake Lonkoy, including chronology and lithology. Zones were defined using CONISS.

(Gloeotrichia) increase gradually. Spirogyra zygospores have maximum values in this zone.

PAZ II $(75-47 \mathrm{~cm})$ is characterized by Cyperaceae, Myriophyllum, Poaceae, Asteroideae and Chenopodiaceae. Ambrosia and the free-floating macrophytes Lemnaceae and Azolla filiculoides gradually increase their values. The coenobia, Pediastrum and Scenedesmus exhibit maximum values in this zone. Low percentage values of Zygnema, Spirogyra, Botryococcus, Tetraedron and Gloeotrichia $(\leq 10 \%)$ are registered.

PAZ III $(47-0 \mathrm{~cm})$ is dominated by maximum values of Cyperaceae. Emergent macrophytes such as Bacopa, Alternanthera, Ranunculus and Phyla canescens are frequently present in this zone. Asteroideae have maximum values and Chenopodiaceae increase slightly towards the top. The NPPs spectra are characterized by maximum values of Botryococcus, Tetraedron and Gloeotrichia and decreasing values of Pediastrum and Scenedesmus.

Four Macrofossils Assemblage Zones (MAZ) were identified (Figure 3):

MAZ I $(136-110 \mathrm{~cm})$ is dominated by Charophytes. Gyrogonites and oospores of Chara sp. A and Chara sp. B present maximum values. Low values of Tolypella and Nitella oospores are registered. Among animal remains, oocytes of Mesostoma (Turbellaria) are present.

In MAZ II (110-75 cm), a replacement of Chara species takes place. Gyrogonites and oospores of Chara sp. C exhibit maximum values, meanwhile values of Chara sp. A and Chara sp. B decrease. The number of Tolypella and Nitella oospores increase, reaching Tolypella highest values. Among the vascular plant remains, Chenopodiaceae, Asteraceae and the submerged macrophytes Zannichellia and Myriophyllum are recorded for the first time at the top of the zone. Oocytes of Mesostoma present increasing values. Plumatella statoblasts, Porifera sponge gemmules and cladoceran ephippia, Daphnia magna, begin to appear, reaching maximum values.
MAZ III $(75-20 \mathrm{~cm})$ contains the highest quantities and diversity of macrofossils. It is characterized by Nitella oospores, the free-floating macrophytes Azolla filiculoides (megaspores) and Lemnaceae (Lemna/Spirodella and Wolffia/Wolffiella seeds) and Chenopodiaceae seeds. Among the animals remains Ceriodaphnia ephippia, Plumatella statoblats, Porifera sponge gemmules and mites reach maximum values.

MAZ IV $(20-0 \mathrm{~cm})$ is characterized by similar values of Nitella oospores, free-floating macrophytes (megaspores and seeds) and different emergent macrophytes such as Schoenoplectus, Carex, Polygonum, Chenopodiaceae and Fabaceae seeds and Asteraceae fruits. Cladoceran ephippia decrease respect to the previous zone. Plumatella (statoblasts), Porifera and minor proportions of mites are also characteristic of this zone.

\section{Lakes Lonkoy, Nahuel Rucá and Hinojales integrated and compared diagrams}

Previous studies based on Hinojales and Nahuel Rucá records (Stutz et al., 2010) proposed the occurrence of sedimentary hiatuses, related to erosional events, as a result of subaerial lakefloor exposures during pronounced droughts that affected the area during the middle-late Holocene (Piovano et al., 2009). This interpretation explains the long time periods contained in short intervals in the lower sections of the cores (Figure 4). The chronological information that is available for lake Lonkoy together with the uniform lithology for the lower section suggests a slow sedimentation rate rather than repeated hiatuses. None of the analysed parameters show a sudden change, as would be expected for a hiatus, but rather smoothed and sustained proxy curves (Figures 2-4; Borel et al., 2003; Stutz et al., 2002, 2006, 2010), suggesting slow sedimentation for all three lakes in the lowest part of the sequences. Even though erosional events cannot be ruled out, 
Lake Lonkoy $\left(37^{\circ} 12^{\prime} \mathrm{S} ; 57^{\circ} 25^{\prime} \mathrm{W}\right)$

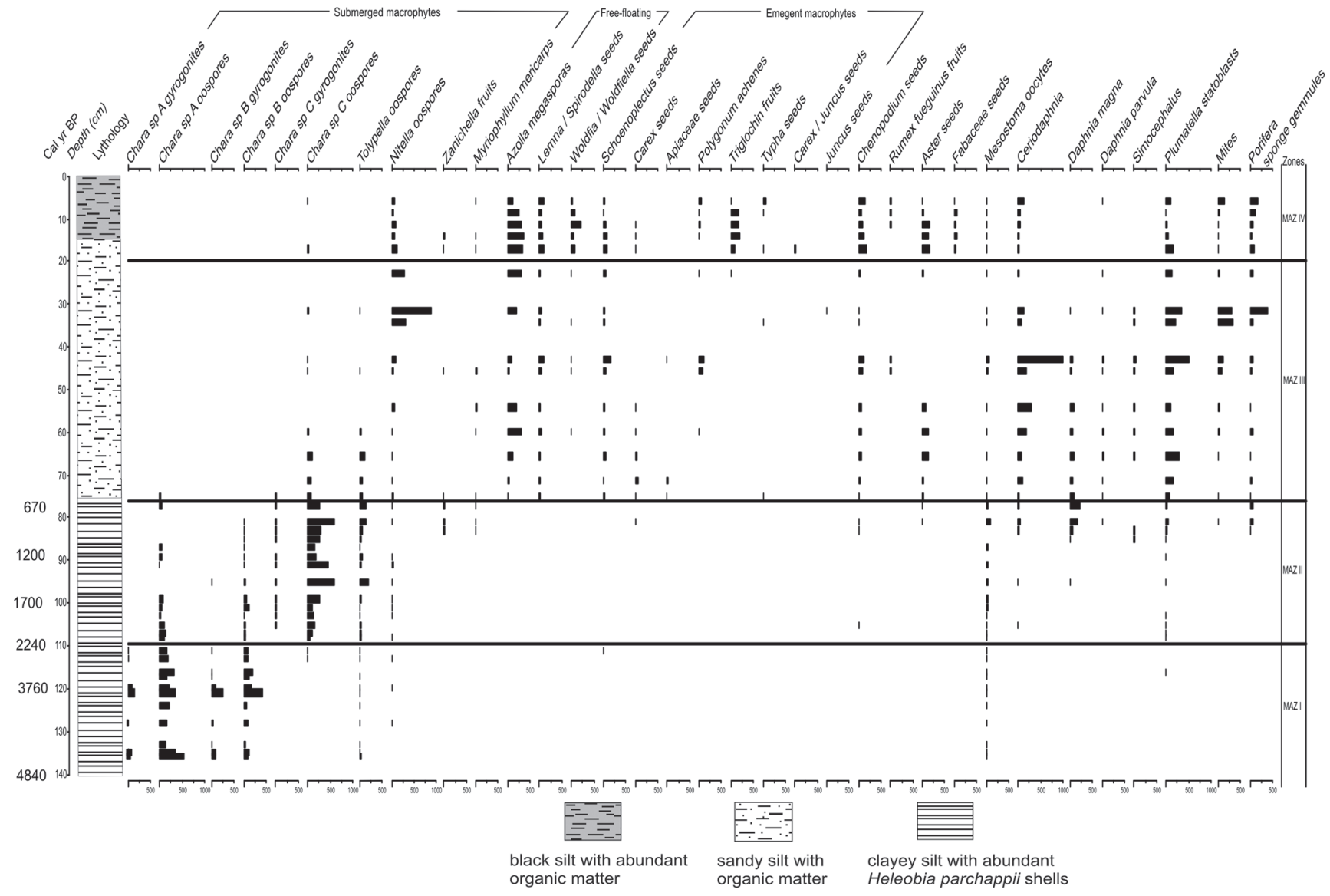

Figure 3. Plant macro remains and accompanying biota from lake Lonkoy, including chronology and lithology. Zones were defined using CONISS.

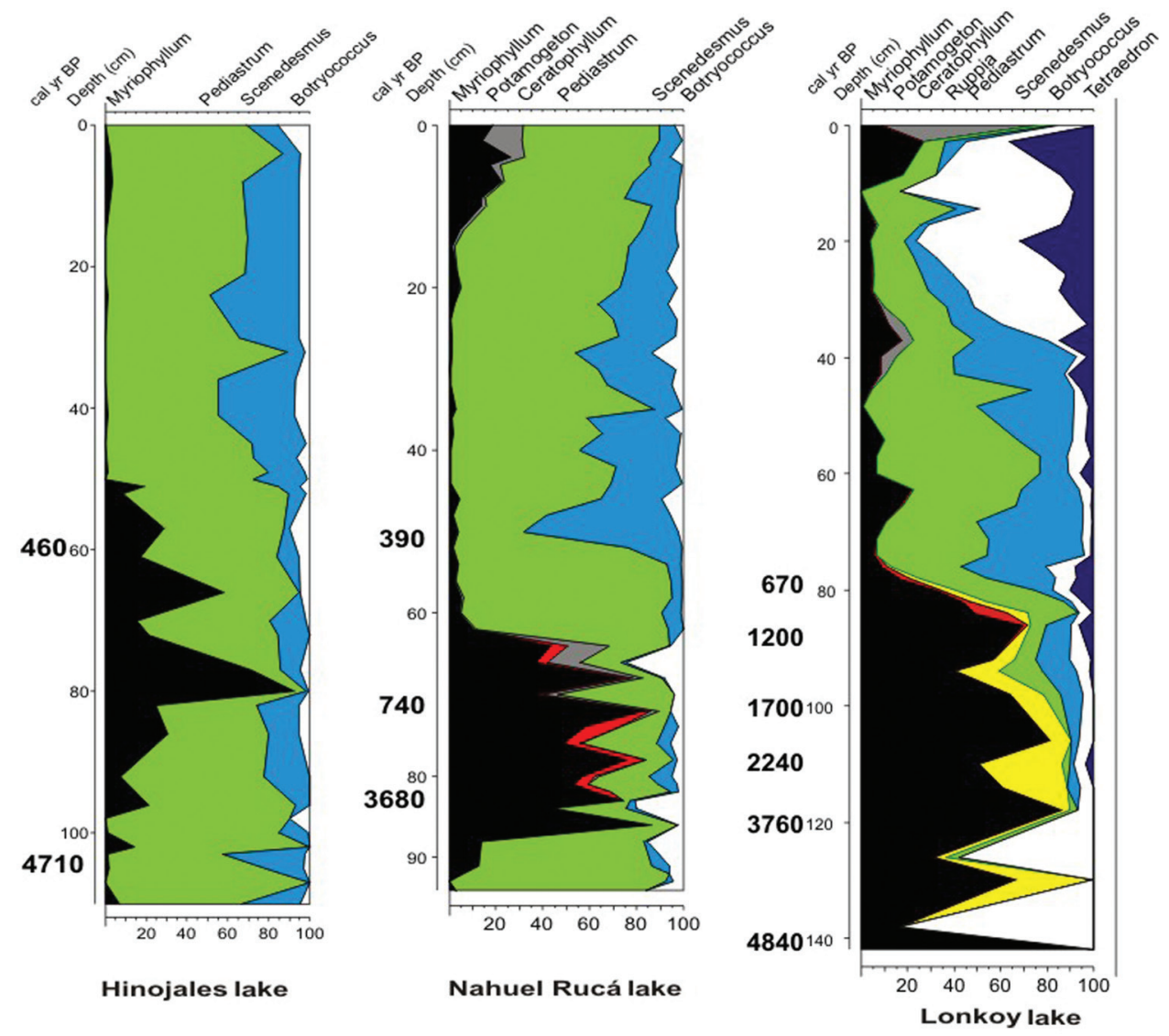

Figure 4. Compared diagrams from lakes Hinojales, Nahuel Rucá and Lonkoy. Including submerged macrophytes (pollen and NPPs) and Phytoplankton (NPPs). 
they were probably not as significant as previously thought. Higher rates of sediment deposition during the last $\sim 700$ years suggest large external input of inorganic material into the lake, as well as increased organic matter deposition due to higher lake productivity.

Comparison of the integrated diagrams for the three lakes (Figure 4) shows similar trends in all records. From the beginning of the sequence to about 700-400 years ago the three lakes are dominated by submerged macrophytes, Myriophyllum, Potamogeton, Ceratophyllum and Ruppia. Thereafter to the present, high values of phytoplankton, Pediastrum, Scenedesmus, Botryococcus and Tetraedron characterize the records. Furthermore, the plant macrofossil analysis from Nahuel Rucá shows the development of an important community of Chara species for the period 3680 to 740 cal. yr BP (Stutz et al., 2010), as in lake Lonkoy (Figure 3).

\section{Discussion}

\section{Lake Lonkoy evolution}

Although pollen and plant macrofossil zones indicate three and four zones, respectively, the lake evolution can be summarized in two main stages. A clear stage is recognized prior to $670 \mathrm{cal}$. yr BP dominated by macrophytes. Subsequently, the lake turned to a turbid phase dominated by phytoplankton, although during the period represented by the topmost $\sim 20 \mathrm{~cm}$, a different phase of turbidity is recognized.

Between 4840 and 1200 cal. yr BP the abundance of Chenopodiaceae in the pollen spectra suggests a halophytic plant community growing in the surroundings of the lake. The dominance of the Peridinium and Cobricosphaeridium and the highest pollen percentages of Ruppia indicate brackish to saline conditions of the water body. However short-periodic pulses of freshwater are suggested by the presence of Myriophyllum, planktonic algae and Zygnemataceae. The abundance of Charophytes indicates a clear lake and/or low water levels and also brakish to saline conditions (García, 1999). Two possibilities are proposed to support brackish and freshwater elements simultaneously, in the lake, and in the surrounding area. Brackish conditions at the lakes Nahuel Rucá and Hinojales were previously interpreted to result from seawater intrusion during the last sea-level highstand (Stutz et al., 2002, 2006, 2010). However, Lonkoy is situated further inland and unlikely to have been reached by the sea (Figure 1; Violante and Parker, 2004; Violante et al., 2001), which led us to propose an alternative explanation that could also be applied to other lakes. It is conceivable that during the middle-late Holocene the ratio of evaporation to precipitation was higher, leading to salinization, low water levels and possibly desiccation. According to Mancini et al. (2005) the eastern and western limits of the Arid-Semiarid Region (ASR), a wide arid and semi-arid region, extending $52^{\circ}-$ $32^{\circ} \mathrm{S}$ and from the Atlantic coast at $44^{\circ} \mathrm{S}$ to the north up to $27^{\circ} \mathrm{S}$ along the eastern flank of the Andes, were displaced eastward $\sim 5000$ cal. yr BP, compared with their 8000 yr BP position, indicating more regional and increasingly arid conditions within the Pampa plain. In this region, the climate became drier during that time as evidenced by sediment, pollen and fauna assemblages (Prieto, 1996; Tonni et al., 1999; Zárate et al., 2000). In the northern part of the Pampa plain, a paleolimnological record indicates an important dry phase at $\sim 4700$ cal. yr BP, as well as dry conditions during most of the Holocene (Piovano et al., 2009). Persistent drier conditions would have caused frequent periodic desiccation of lake Lonkoy and consequently salinization of the catchment area, allowing the development of the halophytic plant community in the surrounding area and abundance of brackish organisms in the lake. Extensive Chara beds would reduce sediment resuspension, which further improves the underwater light availability. The occurrence of occasional rain storms would temporary fill the basin allowing the development of freshwater organisms during short periods. The gradual decrease of brackishsaline elements and the steady increase of Myriophyllum, Potamogeton, planktonic algae and cyanobacteria between 1200 and 670 cal. yr BP suggest the establishment of more frequent freshwater pulses. The dense canopy developed by Myriophyllum would reduce the intensity of light available to plants under the canopy (Blindow, 1992). As a consequence charophytes would eventually decline.

At about $670 \mathrm{cal}$. yr BP a freshwater lake system was well established. High values of Pediastrum and Scenedesmus indicate a shift to the turbid state. The high abundance of these algae would have decreased light conditions producing loss of submerged macrophytes, including charophytes and Myriophyllum. This higher primary productivity could sustain larger populations of Cladocera, bryozoans and other invertebrates that feed on algae and detritus, as is reflected by the greatest abundances of their remains in MAZ III. The decline of charophytes may have also favoured the expansion of limnic species of invertebrates. These benthic macroalgae produce repellent, allelopathic substances that could have inhibited invertebrates and phytoplankton (van Donk and van de Bund, 2002).

PAZ III represents the onset of the modern lake conditions. The plant community is characterized by diverse emergent macrophytes (Schoenoplectus californicus, Bacopa monnieri, Alternanthera philloxeroides, Ranunculus apiifolius, Polygonum punctatum, Phyla canescens, Triglochin striata, Hydrocotyle bonariensis and $H$. ranunculoides) growing as a belt, where a carpet of free-floating plant species (Lemna valdiviana, Wolffiella lingulata, Azolla filiculoides and Ricciocarpus natans) develops. A similar plant association is also found in lake Nahuel Rucá (Stutz et al., 2010), particularly in the topmost $\sim 20 \mathrm{~cm}$, which are interpreted to represent modern lake conditions.

Low values of planktonic algae towards the top of zone PAZ III suggest a different phase of turbidity, which could be the result of suspended material, derived both from sediment resuspension and external loading (Quirós et al., 2002). The unconsolidated silt sediments in the upper section of the core, organic detritus, together with a reduced plant cover on the lake bottom suggest that important processes of wind-induced resuspension of lake sediments have taken place during the last centuries. The resulting suspended matter would reduce irradiance, preventing the growth of planktonic algae but inducing the development of freefloating plants, especially Lemnaceae (O'Farrell et al., 2011). During the 20th century, the shallow lakes in this region became more eutrophic because of human activities, mainly an increase in agriculture. The eutrophication took place particularly in lakes highly exposed to intense land use of their drainage basins (Rennella and Quirós, 2006). In lake Lonkoy, the expansion of freefloating plants and emergent macrophytes that concentrate their biomass in the upper water layer can be related with an increase in nutrient loading to the lake.

\section{Shifts from clear to turbid states during the late Holocene}

The alternative stable state hypothesis explains the behaviour of shallow lakes at ecological timescales, where shifts from clear to turbid states occur in short periods of time (e.g. Blindow et al., 1993; Hargeby et al., 2004, 2007; Ibelings et al., 2007; Sayer et al., 2006). The three lakes analyzed in this study show a clear state dominated by macrophytes during a long period of about 4000 years. Then, these lakes shifted to a turbid state, dominated first by phytoplankton and then by resuspended sediment. At lakes Lonkoy and Nahuel Rucá the shift from a clear to turbid state may have occurred at $\sim 700 \mathrm{cal}$. yr BP, while for lake 
Hinojales the available radiocarbon date suggests a later shift, around $\sim 400$ cal. yr BP.

These shifts could be due to intrinsic processes involving, for example, changes in nutrient availability. This would assume an individualistic behaviour of the three lakes. However, the three lakes have changed state during broadly the same time period, although the exact timing of the shift is somewhat uncertain because of the limited dating control. Accepting a broadly synchronous shift of the three lakes argues for an external trigger for the change that would have influenced the three lakes at the same time.

The onset of agricultural activities would have affected the environment on a large scale; however, the first settlements in the area are known from the 19th century and the intensive agriculture activities began in the Pampa plain at the beginning of the 20th century (Ghersa and León, 2001). Then, the only other forcing factor that works on a larger scale is climate.

As mentioned above, dry conditions persisted throughout the Pampa plain between 5000 and 1000 cal. yr BP (Mancini et al., 2005; Piovano et al., 2009), interrupted by warm and wet conditions attributed to the Medieval Climatic Anomaly (MCA) (Piovano et al., 2009; Tonni et al., 1999). This climatic anomaly, well established in the Northern Hemisphere, has been repeatedly reconstructed in southern South America during the last decades (e.g. Haberzettl et al., 2005; Morales et al., 2009; Moy et al., 2008; Stine, 1994; Villalba, 1994). Coincident with the MCA important process of pedogenesis and development of large wetlands took place within the region (e.g. Carignano, 1999; Piovano et al., 2009). Precipitation reconstructions based on pollen sequences inferred values of $100 \mathrm{~mm}$ greater than present in the southwest and center part of the Pampa grasslands (Tonello and Prieto, 2010). The above climatic conditions would have promoted permanent fresh water in the lake basins with the development of diverse communities of emergent and floating macrophytes as well as an increase of phytoplankton biomass. As a result, light limitation would induce the decline of submerged macrophyte, causing a shift from macrophyte-dominated clear water to a microalgaedominated turbid state. This shift of states could also have occurred at several other lakes in the region in the same time period. However, both types of lake, macrophyte-dominated clear water and microalgae-dominated turbid lakes, occur in the region today (Allende et al., 2009; Quirós et al., 2002) indicating that additional factors may be important to cause this shift of state.

The uppermost part of the core, $\sim 20 \mathrm{~cm}$, represents one of the three types of lakes described by Quirós et al. (2002) from the Pampa plain: inorganic-turbid lakes. In these lakes, turbidity is mostly due to sediment (organic detritus and silt particles) resuspension caused by wave action, and planktonic algae and macrophyte development is low. The inorganic-turbid type encompasses lakes clearly limited in their productivity by light availability, and would be the result of direct human impact on their drainage basins, since their surroundings are dominated by intensive farming activities.

\section{Conclusions}

This study shows that the long-term dynamics of macrophytes and algal dominance in shallow lakes within the Pampa plain can be reconstructed, and that shifts may be linked to regional environmental change. The three fossil records document similar lake developments during the mid and late Holocene, with changes occurring broadly at the same time. Three main phases are recognized: (i) a clear lake dominated by macrophytes that prevailed until 700 cal. yr BP at lakes Lonkoy and Nahuel Rucá, and until $\sim 400$ cal. yr BP at lake Hinojales; (ii) afterwards the lakes changed to a turbid state dominated by phytoplankton; and (iii) recently, the lakes have turned inorganic-turbid because of the high amount of suspended inorganic material. The shift from clear to turbid state may be caused by a regional climatic shift towards wetter conditions after $1000 \mathrm{cal}$. yr BP, during the Medieval Climate Anomaly. Clear and phytoplankton-turbid lakes occur today within the region, suggesting that additional factors may have played a role to cause the shift.

\section{Acknowledgements}

We thank Josefina Pueyrredón de Lanus for permission to work on Lake Lonkoy, and the Pampa grassland shallow lakes team: Diego Navarro, Eugenia de Porras, Antonio González, Claudio De Francesco, Gabriela Hassan, Laura Ferrero and Gonzalo Sottile for their support during coring activities. Andy Lotter provided valuable comments on an early version of the manuscript, and constantly encouraged us to publish these results. Thomas Giesecke provided useful comments on the manuscript.

\section{Funding}

Financial support was provided by CONICET-PIP 1265, EXA 529/10 and EXA 587/12. We thank the (NSF)-Arizona AMS Facility and $\mathrm{T}$ Jull for financial support for dating.

\section{References}

Allende L, Tell G, Zagarese H et al. (2009) Phytoplankton and primary production in clear-vegetated, inorganic-turbid, and algal-turbid shallow lakes from the pampa plain (Argentina). Hydrobiologia 624: 45-60.

Beisner BE, Haydon DT and Cuddington K (2003) Alternative stable states in ecology. Frontiers in Ecology and the Environment 1(7): 376-382.

Blindow I (1992) Long- and short-term dynamics of submerged macrophytes in two shallow eutrophic lakes. Freshwater Biology 28: 15-27.

Blindow I, Andersson G, Hargeby A et al. (1993) Long-term pattern of alternative stable states in two shallow eutrophic lakes. Freshwater Biology 30: $159-167$.

Borel CM (2007) Algas no silíceas y acritarcos de depósitos costeros holocenos en el arroyo La Ballenera, provincia de Buenos Aires, Argentina. Ameghiniana 44: 359-366.

Borel CM, Guerstein GR and Prieto AR (2003) Palinomorfos acuáticos (algas y acritarcos) del Holoceno de la laguna Hinojales (Buenos Aires, Argentina): Interpretación paleoecológica. Ameghiniana 40: 531-544.

Carignano CA (1999) Late Pleistocene to recent climate change in Córdoba province, Argentina: Geomorphological evidence. Quaternary International 57-58: 117-134.

Faegri K and Iversen J (1992) Texbook of Pollen Analysis. IV Edition, Faegri K, Kalana PE and Krzywinski K. John Willey and Sons.

Fontana SL (2005) Holocene vegetation history and palaeoenvironmental conditions on the temperate Atlantic coast of Argentina, as inferred from multi-proxy lacustrine records. Journal of Paleolimnology 34: 445-469.

Fontana SL (2007) Radiocarbon chronologies of Holocene lacustrine sediments from the southern coast of Buenos Aires province, Argentina. Radiocarbon 49: 103-116.

García A (1999) Quaternary charophytes from Salina del Bebedero, Argentina: Their relation with extant taxa and palaeolimnological significance. Journal of Paleolimnology 21: 307-323.

García-Rodriguez F, Stutz S, Inda H et al. (2010) A multiproxy approach to inferring Holocene paleobotanical changes linked to sea-level variation, paleosalinity levels, and shallow lake alternative states in Negra Lagoon, SE Uruguay. Hydrobiologia 646: 5-20.

Ghersa CM and León RJC (2001) Ecología del Paisaje Pampeano: Consideraciones para su manejo y conservación. In: Naveh $\mathrm{Z}$ and Lieberman AS (eds) Ecología de Paisajes, Teoría y Aplicación. Facultad de Agronomía, pp. 471-512.

Grimm EC (1987) CONISS: A Fortran 77 program for stratigraphically constrained cluster analysis by the method of incremental sum of squares. Computers \& Geosciences 13: 13-35.

Haberzettl T, Fey M, Lucke A et al. (2005) Climatically induced lake level changes during the last two millennia as reflected in sediments of Laguna Potrok Aike, southern Patagonia (Santa Cruz, Argentina). Journal of Paleolimnology 33: 283-302.

Hargeby A, Blindow I and Andersson G (2007) Long-term patterns of shifts between clear and turbid states in lake Krankesjön and lake Takern. Ecosystems 10: 28-35. 
Hargeby A, Blindow I and Hansson LA (2004) Shifts between clear and turbid states in a shallow lake: Multi-causal stress from climate, nutrients and biotic interactions. Archiv für Hydrobiologie 161(4): 433-454.

Heiri O, Lotter AF and Lemcke G (2001) Loss on ignition as a method for estimating organic and carbonate content in sediments: Reproducibility and comparability of results. Journal of Paleolimnology 25: 101-110.

Herzschuh U, Zhang C, Mischke S et al. (2005). A late Quaternary lake record from the Qilian Mountains (NW China): Evolution of the primary production and the water depth reconstructed from macrofossil, pollen, biomarker, and isotope data. Global and Planetary Change 46: 361-379.

Ibelings BW, Portielje R, Lammens EHRR et al. (2007) Resilience of Alternative Stable States during the recovery of shallow lakes from eutrophication: Lake Veluwe as a case of study. Ecosystems 10: 4-16.

Jeppesen E, Jensen JP, Kristensen P et al. (1990) Fish manipulation as a lake restoration tool in shallow, eutrophic, temperate lakes 2: Thresholds levels, long-term stability and conclusions. Hydrobiologia 200-201: 219-228.

Karst TL and Smol JP (2000) Paleolimnological evidence of limnetic nutrient concentration equilibrium in a shallow, macrophyte-dominated lake. Aquatic Science 62: 20-38.

McCormac FG, Hogg AG, Blackwell PG et al. (2004) SHCal04 Southern Hemisphere calibration 0-1000 cal BP. Radiocarbon 46: 1087-1092.

Mancini MV, Paez, MM, Prieto AR et al. (2005) Mid-Holocene climatic variability reconstruction from pollen records $\left(32^{\circ}-52^{\circ} \mathrm{S}\right.$, Argentina). Quaternary International 132: 47-59.

Markgraf V and D'Antoni HL (1978) Pollen Flora of Argentina. Modern Spore and Pollen Types of Pteridophyta, Gimnospermae and Angiospermae. Tucson AZ: The University of Arizona Press.

Morales M, Barberena R, Belardi JB et al. (2009) Reviewing human-environment interactions in arid regions of southern South America during the past 3000 years. Palaeogeography, Palaeoclimatology, Palaeoecology 281: 283-295

Moss B, Standsfield J, Irvine K et al. (1996) Progressive restoration of a shallow lake: A 12-year experiment in isolation, sediment removal and biomanipulation. Journal of Applied Ecology 33: 71-86.

Moy Cm, Dunbar RB, Moreno PI et al. (2008) Isotopic evidence for hydrologic change related to the westerlies in SW Patagonia, Chile, during the last milennium. Ouaternary Science Reviews 27: 1335-1349.

O'Farrell I, Izaguirre I, Chaparro G et al. (2011) Water levels as the main driver of the alternation between a free-floating plant and a phytoplankton dominated state: A long-term study in a floodplain lake. Aquatic Sciences 73 : 275-287.

Piovano EL, Ariztegui D, Córdoba F et al. (2009) Hydrological variability in South America below the tropic of Capricorn (Pampas and Patagonia, Argentina) during the last 13.0 ka. In: Vimeux F (ed.) Past Climate Variability in South America and Surrounding Regions. Developments in Paleoenvironmental Research, Springer, pp. 323-351.

Prieto AR (1996) Late quaternary vegetational and climatic changes in the Pampa grassland of Argentina. Quaternary Research 45: 73-88.

Quirós R, Renella AM, Boveri MB et al. (2002) Factores que afectan la estructura y el funcionamiento de las lagunas pampeanas. Ecología Austral 12 : $175-185$.

Rennella AM and Quirós R (2006) The effects of hydrology on plankton biomass in shallow lakes of the Pampa plain. Hydrobiologia 556: 181-191.

Sayer CD, Burgess A, Kari K et al. (2010) Long-term dynamics of submerged macrophytes and algae in a small and shallow, eutrophic lake: Implications for the stability of macrophyte-dominance. Freshwater Biology 55: $565-583$
Sayer CD, Hoare DI, Simpson GL et al. (2006) TBT causes regime shifts in shallow lakes. Environmental Science Technology 40: 5269-5275.

Scheffer M and Carpenter SR (2003) Catastrophic regime shifts in ecosystems: Linking theory to observation. Trends in Ecology and Evolution 18(12): 648-656.

Scheffer M and Jeppesen EJ (2007) Regime shifts in shallow lakes. Ecosystems 10: $1-3$.

Scheffer M, Carpenter S, Foley JA et al. (2001) Catastrophic shifts in ecosystems. Nature 413: 591-596.

Scheffer M, Hosper SH, Meijer ML et al. (1993) Alternative equilibria in shallow lakes. Trends in Ecology and Evolution 8: 275-279.

Stine S (1994) Extreme and persistent drought in California and Patagonia during Medieval time. Nature 369: 546-549.

Stuiver M, Reimer PJ and Reimer RW (2005) Calib 5.0.1. Available at: http:// calib.qub.ac.uk/calib/

Stutz S, Borel CM, Fontana SL et al. (2010) Late Holocene environmental evolution of Nahuel Rucá freshwater shallow lake, SE Pampa grasslands, Argentina. Journal of Paleolimnology 44(3): 761-775.

Stutz S, Prieto AR and Isla FI (2002) Historia de la vegetación de la laguna Hinojales, sudeste de la provincia de Buenos Aires, Argentina. Ameghiniana 39: 85-94.

Stutz S, Prieto AR and Isla FI (2006) Holocene evolution of the Mar Chiquita coastal lagoon area, Argentina, indicated by pollen analysis. Journal of Quaternary Science 21: 17-28.

Tonello M and Prieto AR (2010) Tendencias climáticas para los pastizales pampeanos durante el Pleistoceno tardío - Holoceno: Estimaciones cuantitativas basadas en secuencias polínicas fósiles. Ameghiniana 47(4): 501-514.

Tonni EP, Cione AL and Figini AJ (1999). Predominance of arid climates indicated by mammals in the pampas of Argentina during the Late Pleistocene and Holocene. Palaeogeography, Palaeoclimatology, Palaeoecology 147: 257-281

Tricart R (1973) Geomorfología de la Pampa Deprimida. Base para los estudios edafológicos y agronómicos. XII Colección Científica INTA.

van Donk E and Gulatti RD (1995) Transition of a lake to turbid state 6 years after biomanipulation: Mechanisms and pathways. Water Science and Technology 32(4): 197-206.

van Donk E and van de Bund WJ (2002) Impact of submerged macrophytes including charophytes on phyto- and zooplankton communities: Allelopathy versus other mechanisms. Aquatic Botany 72: 261-274.

Vervoorst F (1967) La vegetación de la República Argentina. VII Las comunidades vegetales de la depresión del Salado (Provincia de Buenos Aires). INTA Serie Fitogeográfica 7 Buenos Aires.

Villalba R (1994) Fluctuaciones climáticas en latitudes medias de América del Sur durante los últimos 1000 años: Sus relaciones con la Oscilación del Sur. Revista Chilena de Historia Natural 67: 453-461.

Violante RA (1992) Ambientes sedimentarios asociados a un sistema de barrera litoral del Holoceno en la llanura costera al sur de Villa Gesell, Provincia de Buenos Aires. RAGA 47: 201-214.

Violante RA and Parker G (2004). The post-last glacial maximum transgression in the la Plata River and adjacent inner continental shelf, Argentina. Quaternary International 114: 167-181.

Violante RA, Parker G and Cavallotto JL (2001) Evolución de las llanuras costeras del este bonaerense entre la bahía Samborombón y la laguna Mar Chiquita durante el Holoceno. RAGA 56: 51-66.

Zárate M, Kemp RA, Espinosa M et al. (2000) Pedosedimentary and palaeoenvironmental significance of a Holocene alluvial sequence in the southern Pampas, Argentina. The Holocene 10: 481-488. 